\author{
І.В. Корнієнко ${ }^{1}$, С.П. Корнієнко ${ }^{1}$, В.А. Дмитрієв ${ }^{2}$, А.Г. Павленко ${ }^{2}$, Д.О. Камак ${ }^{2}$ \\ ${ }^{1}$ Національний університет "Чернігівська політехніка", Чернігів \\ ${ }^{2}$ Державний науково-дослідний інститут випробувань і сертифікаиії озброєння \\ та військової техніки, Чернігів
}

\title{
ВИЗНАЧЕННЯ ПАРАМЕТРІВ ЯКОСТІ ОЦІНОК СТОХАСТИЧНИХ ХАРАКТЕРИСТИК ВИПРОБУВАНОГО ЗРАЗКА ОЗБРОЄННЯ ТА ВІЙСЬКОВОÏ ТЕХНІКИ
}

У статті розглянуті теоретичні питання формування показників якості оцінок стохастичних величин з використанням математичного апарату теорії ймовірностей. Обгрунтовано варіанти розрахунків показників якості очінки для випадків відсутності або наявності початкових імовірнісних характеристик, точкових або інтервальних оцінок стохастичної величини. Для випадку інтервального оцінювання показано теоретичну можливість збереження значень показників якості оцінок при навмисному скороченні кількості повторень дослідів за умови одержання позитивних результатів досліджень. Запропоновано використання графічного інтерфейсу для знаходження оптимального балансу між точністю та надійністю одержуваних оцінок. Для практичної реалізації розроблено алгоритм розрахунку точності і надійності оцінок стохастичних характеристик (параметрів) випробуваного зразка, який можна використати в основі функиіонального модуля у підсистеми планування випробувань автоматизованої системи супроводження випробувань озброєння та військової техніки.

Ключові слова: автоматизація, випробування, оцінка, точність, надійність, озброєння та військова техніка.

\section{Вступ}

Постановка проблеми. Одним 3 основних проблемних питань при проведенні випробувань новітніх зразків озброєння та військової техніки (ОВТ) є питання забезпечення достовірності одержаних результатів. Насамперед, це стосується стохастичних параметрів і характеристик випробуваного зразка. Зазвичай, така проблема вирішується достатнім обсягом однотипних повторень випробування, що проводяться в однакових умовах, за результатами яких статистичну частоту настання “успішноі” події, з певною мірою надійності і точності, приймають за ймовірнісну характеристику стохастичного параметра чи характеристики зразка.

Проте інколи, через низку причин, які відокремлюють і уособлюють випробування зразків ОВТ від продукції цивільного призначення (за певним виключенням), задача забезпечення якості одержуваних оцінок випробувань представляється нездійсненою. Як правило, таке стається внаслідок руйнівної природи випробувань, при якій дослідний зразок, часто виконаний в одиничному екземплярі (або дрібносерійному: у кількості 2-3 екземпляри) піддається зовнішньому руйнівному впливу при надто великій вартості досліджуваного зразка; неможливості масових (а інколи навіть й одиничних) випробувань через надвелику шкоду природному середовищу тощо. Наведені причини унеможливлюють проведення випробувань 3 достатньою кількістю повторень, результат яких може забезпечити статистичні показники надійності і точності оцінки.
3 іншого боку, в теперішній час ситуація, що склалася в країні, обумовлює нагальну потребу Збройних Сил України в оновлені і осучасненні зброї та військової техніки, що перебуває на озброєнні. Ця потреба обумовила суттєве зростання кількості зразків ОВТ, які надходять на випробування та сертифікацію до випробувальних установ Збройних Сил України [1-2]. Зростання потоку вимог на випробування вимагає від випробувальних установ пошуку та прийняття оптимальних рішень щодо розподілу наявних часових та людських ресурсів, а також відшукання способів економії ресурсів для проведення випробувань. Окремо слід зауважити, що випробування зразка ОВТ може тривати доволі великий час, і в умовах гострої потреби у новітньому озброєнні під час особливого періоду, що триває в Україні, може виникати необхідність максимального прискорення всіх процесів (робіт), з яких складається випробування. Це, в свою чергу, також може виступати обмежувальним чинником, що супроводжує проведення великих і тривалих серій випробувань.

Все вищевикладене можна звести до одного інколи існує об'єктивна потреба у навмисному скороченні кількості повторень випробування зразка, що, з одного боку, може вплинути на якість і достовірність одержуваних оцінок результатів випробувань тієї чи іншої характеристики, але, з іншого боку, дозволить закінчити цілісне випробування зразка ОВТ і визначити оцінку якості певної стохастичної характеристики чи параметру випробуваного зразка. При цьому, постає задача визначення показ- 
ників якості оцінки, які забезпечуються проведеною кількістю повторень випробування.

Аналіз останніх досліджень та публікацій. На даний момент загальні положення щодо проведення випробувань ОВТ в Україні зазначені у низці нормативно-правових актів [3-5], порядок проведення випробувань дослідних зразків ОВТ регламентується стандартом [6], загальний порядок розробки програм і методик випробувань визначений у стандарті [7], хід проведення випробувань серійних виробів ОВТ визначений у [8]. Широкий спектр виробів оборонного призначення обумовив відсутність (на сьогодні) єдиного та універсального методичного підходу у питанні планування кількісних показників випробувань стохастичних характеристик (параметрів) зразків ОВТ. При цьому, дослідники-випробувачі при розробці таких методик мають користуватися нині добре розвиненим математичним апаратом теорії планування випробувань технічних виробів, наприклад [9-11] (у тому числі військового призначення [12-13]), положеннями теорії ймовірностей і математичної статистики в частині статистичного оцінювання стохастичних величин, наприклад [14-16]. Нині продовжується розвиток теоретичних положень і пошук практичних рішень щодо забезпечення якості результатів випробувань [17-19] та можливості зменшення кількісного плану випробувань [20-21]. Чимало уваги приділяється питанням автоматизації систем випробування і контролю, наприклад [22-23].

Для забезпечення якості масових випробувань зразків ОВТ запропоновано використання автоматизованої підсистеми планування випробувань [24], в якій пропонується використовувати функціональні модулі розрахунку кількісних планів випробування для одержання якісних точкових i інтервальних оцінок стохастичних характеристик (параметрів) випробуваного зразка [25-26].

Виділення недосліджених раніше частин загальної проблеми. На доданок до постановочної частини статті окреслимо проблему автоматизації випробувань. На сьогодні не викликає сумнівів, що одним 3 можливих способів підвищення продуктивності (ефективності) будь якої організації, установи чи системи є повна або часткова автоматизація процесів, що супроводжують іiі функціонування і які можуть бути алгоритмізовані. Не є виключенням і установи та організації, які проводять випробування складних технічних систем, у тому числі і зразків OBТ, при чому, метою такої автоматизації $є$ виключення “ручного” виконання рутинних операцій, що супроводжують всі стадії випробування ОВТ.

Загальний методологічний підхід до випробувань визначає підготовчу стадію, під час якої здійснюється розробка програми і методик проведення випробувань. Без сумніву, фактично будь-який зразок ОВТ володіє множиною (або принаймні однією) стохастичних характеристик (параметрів) внутрішнього (надійність, успішність ураження цілі, пропускна здатність тощо) або зовнішнього характеру (стійкість до зовнішнього впливу, завадозахищеність тощо), що вимагає застосування математичного апарату розрахунку кількісного плану випробувань для одержання оцінок заданої якості. Зважаючи на це, на думку авторів, доцільно використовувати автоматизований модуль розрахунку кількісних планів, функціональна схема якого запропонована у [25] і представлена на рис. 1.

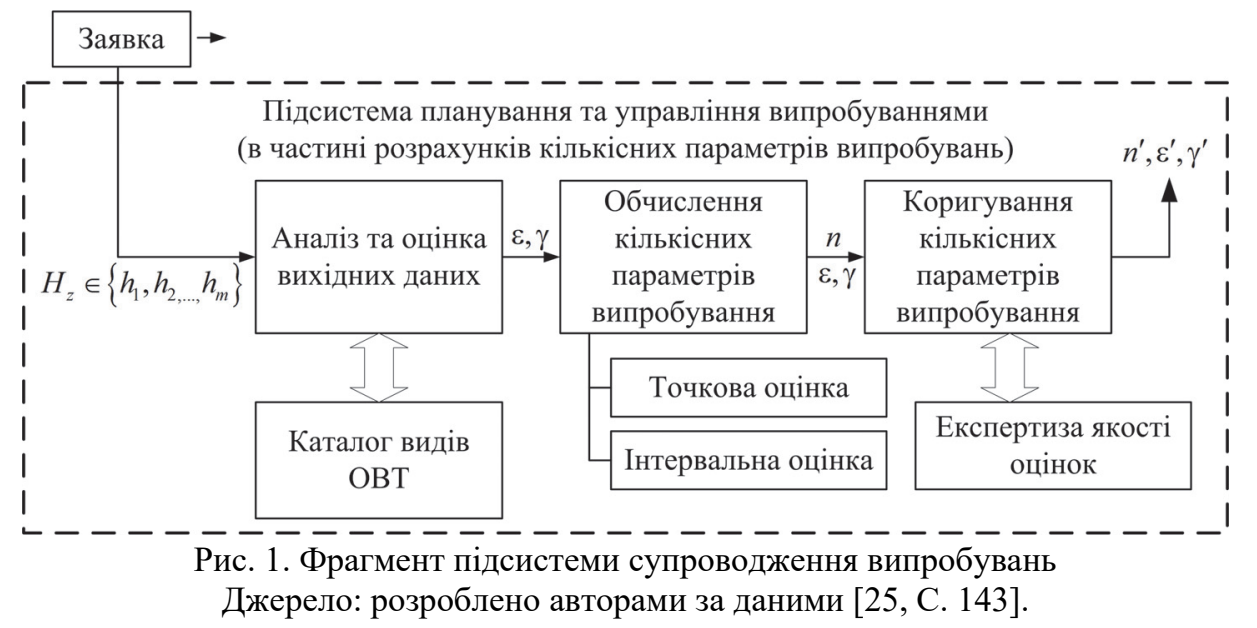

На рис. 1 літерами $n, \gamma$ і $\varepsilon$ позначені відповідно кількість однотипних повторень досліду, надійність і точність одержуваної оцінки $h_{i}$-ї стохастичної характеристики (параметру) зразка. При цьому на виході модулю маємо кореговані значення $n^{\prime}, \gamma^{\prime}$ і $\varepsilon^{\prime}$, які сформовані на основі міркувань з обмежен- ня потенційно-можливого проведення повторень дослідів. Придатність одержуваної оцінки, якість якої, безумовно, буде нижчою за потрібну, так як $n^{\prime}<n$, буде визначаться якісними показниками $\gamma^{\prime}$ i $\varepsilon^{\prime}$, або їх балансом. Використання такого модулю має на меті скорочення часу на підготовчі роботи та 
відшукання оптимального плану експериментальних досліджень випробуваного зразка ОВТ.

Мета статті. Розробити, підготувати та алгоритмізувати механізм розрахунку показників якості одержуваної оцінки стохастичних характеристик (параметрів) випробовуваного зразка ОВТ при навмисному скороченні кількісного плану випробувань.

\section{Виклад основного матеріалу}

Забезпечення належних показників якості одержуваної в результаті випробувань оцінки стохастичної характеристики (параметру) випробуваного зразка ОВТ здійснюється на етапі розрахунку кількості $n$ однотипних повторень досліду. За теоремою Бернуллі, яка $\epsilon$ найпростішою формою, так званого, “закону великих чисел”: $\lim _{n \rightarrow \infty} P(|W-p|<\varepsilon)=1$, при великій кількості повторень випробування статистична частота настання “успіху” випробування $W$ наближається до ймовірності $p ; W=\frac{k}{n}$, де $k$ - кількість “успішних" випробувань $3 n$ повторень. На основі інтегральної теореми Муавра - Лапласа ступінь наближення $W \rightarrow p$ можна визначити за допомогою параметрів якості одержуваної оцінки, а саме ii точності $\varepsilon$ i надійності $\gamma$. Так, при обмеженій кількості повторень $n$ надійність оцінки $\gamma[15 ; 25]$ :

$$
\lim _{n \rightarrow \infty} P(|W-p|<\varepsilon) \simeq \gamma
$$

Для практичної оцінки $|W-p|<\varepsilon$ використовують функцію Лапласа $\Phi(x)=\frac{1}{\sqrt{2 \pi}} \int_{0}^{x} e^{-\frac{t^{2}}{2}} d t[14 ; 16]$ :

$$
P(|W-p|<\varepsilon) \simeq 2 \Phi(x),
$$

де $x=\varepsilon \sqrt{\frac{n}{p q}}, q$-ймовірність “неуспіху” досліду, $q=1-p$.

3 (1) і (2) надійність оцінки $\gamma$ пов'язана 3 функцією Лапласа співвідношеннями $\gamma=2 \Phi(x)$; $\Phi(x)=\frac{\gamma}{2}$. У звичайній постановці задачі, відшукання мінімально-необхідної кількості однотипних дослідів $n$ здійснюється з виразу

$$
x_{\gamma}=\varepsilon \sqrt{\frac{n}{p q}},
$$

де $x_{\gamma}$ - табульоване значення аргументу функції Лапласа для $\gamma$. Обчислена з виразу (3) $n$ забезпечуватиме якість оцінки $\varepsilon$ і $\gamma$ [25]. У нашому випадку є зворотна задача: необхідно відшукати парамет- ри якості оцінки $\varepsilon^{\prime}$ і $\gamma^{\prime}$ для кількості дослідів $n^{\prime}$, $n^{\prime}<n$. Незвичним для представлення результатів $€$ те, що ми фактично маємо дві невідомі величини в одному рівнянні:

$$
\frac{x_{\gamma^{\prime}}}{\varepsilon^{\prime}}=\sqrt{\frac{n^{\prime}}{p q}} .
$$

Тобто, на практиці, при використанні автоматизованого модулю планування випробувань, відображення результатів обчислень неможливе у вигляді двох фіксованих значень $\varepsilon^{\prime}$ i $\gamma^{\prime}$, що в свою чергу, передбачає використання у інтерфейсі модулю певних графічних інструментів для варіювання одержуваними значеннями, або використання деякого математичного механізму (наприклад, метод Парето чи будь-який інший оптимізаційний метод) для знаходження оптимального балансу між точністю і надійністю оцінки.

Окремо слід зауважити, що відшукання параметрів якості оцінок результатів досліджень може відбуватися для різних потенційно можливих сценаріїв випробування, які можуть вплинути на значення параметрів якості оцінки. Окреслимо їх:

- випробування характеристики (параметру) зразка ОВТ проводяться вперше, і будь які апріорні дані щодо реалізації стохастичної величини відсутні;

- $\epsilon$ відомості щодо початкової ймовірнісної характеристики реалізації стохастичної величини, яку в результаті випробувань потрібно точно підтвердити;

- відомості щодо початкової ймовірнісної характеристики реалізації стохастичної величини задані у вигляді “не гірше ніж”.

Зупинимось докладніше на кожному з них. У випадку повної невизначеності щодо початкової імовірності реалізації характеристики (параметру) зразка у виразі (4) невідомими є значення $p$ i $q$. Тоді, для одержання гарантованої якості випробувань необхідно прийняти найгірший випадок, коли кількість необхідних повторень буде максимальною. Найгіршим випадком у цій ситуації є рівність $p$ і $q$, $p=q=0,5$, що докладно показане у [25]. Для такого випадку результат балансу між параметрами якості оцінки для різних значень $n^{\prime}$ зображений на рис. 2 .

Відлік по осях графіку на рис. 2 обрано на основі прийнятних у техніці значеннях якості оцінки [27]. 3 наведеного очевидно, що сягнути якісних оцінок при повній невизначеності імовірнісної характеристики при малій кількості повторень досліду представляється неможливим.

У випадку наявних даних щодо початкової ймовірнісної характеристики $p$ реалізації стохастичної величини параметру зразка маємо родину кривих, зображених на графіку рис. 3 . 


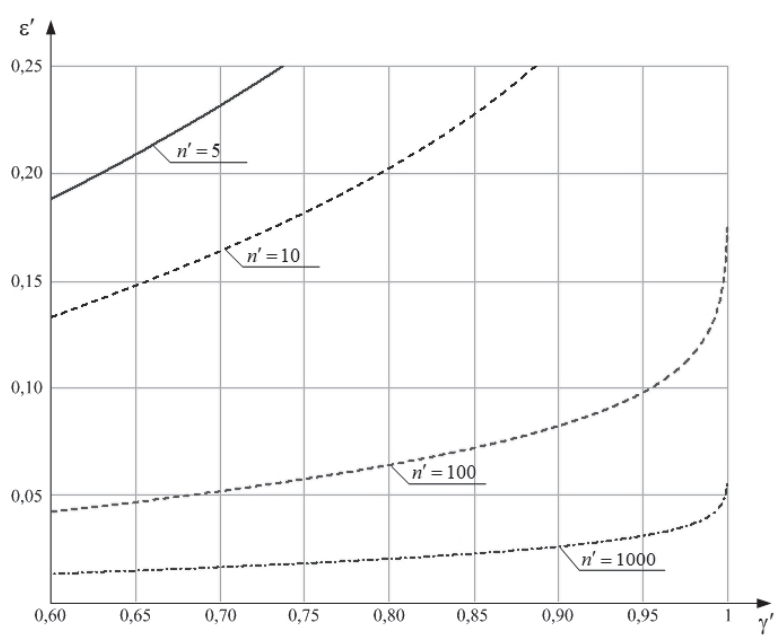

Рис. 2. Співвідношення між показниками якості оцінки при різних кількостях повторень досліду та відсутньої початкової ймовірнісної характеристики Джерело: розроблено авторами.

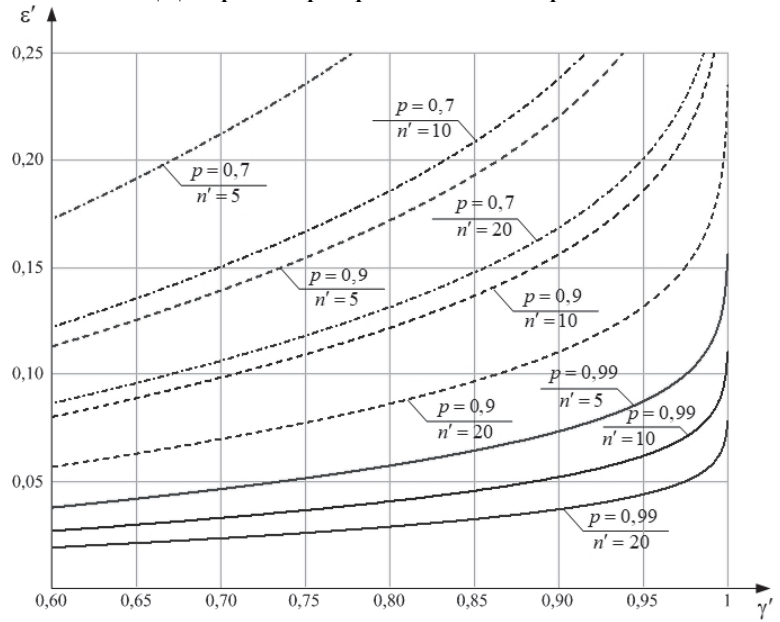

Рис. 3. Співвідношення між показниками якості оцінки при різних кількостях повторень досліду та заданої початкової ймовірності $p$ реалізації стохастичного показника Джерело: розроблено авторами.

3 рис. 3 видно, що прийнятні показники якості оцінки можна отримати навіть при невеликій кількості повторень досліду, причому великий вплив на значення показників якості чинить задана розробником початкова ймовірність $p$.

Розглянемо сценарій, коли початкова характеристика стохастичної величини задана у вигляді “не гірше ніж”. Припустимо, що нам необхідно підтвердити або спростувати початкову ймовірність $p$ задану у вигляді “не гірше ніж”. В цьому разі довірчий інтервал, що визначається точністю $\varepsilon$, має обмеження тільки “знизу” або “зверху”, тобто шукана ймовірність $p^{*}$ може знаходитись в інтервалах $0 \leq p^{*} \leq p$ для випадку “не більше ніж”, i $p \leq p^{*} \leq 1$ у випадку “не менше ніж”.

Теоретично, виходячи з виразів (1) і (3), не зважаючи на певне розширення довірчого інтервалу (за рахунок верхньої або нижньої межі), розрахована кількість повторень випробування має бути такою ж, як і при точкових оцінках початкової ймовірності $p$. Проте, у деяких випадках, як це було показане у [26], позитивні результати випробувань можуть певною мірою скоротити кількість повторень дослідів, що у нашому випадку може виявитись корисним для показників якості одержуваної оцінки. Для докладного представлення ідеї покращення показників якості оцінки розглянемо розрахунки мінімальнонеобхідної кількості повторень випробування [25] для загальноприйнятих дискретних значень точності та надійності одержуваних оцінок [27] і різного значення ймовірнісної характеристики випробувального зразка (табл. 1) та очікуваного числа спостережуваних “успіхів” (табл. 2).

Нехай кількість повторень, що забезпечують нормативні показники якості оцінки $\varepsilon$ і $\gamma$, становить $n$, очікуване число “успіхів” становить $k$, а розглядуваний інтервал $p \leq p^{*} \leq 1$. Внаслідок об'єктивних обмежень потенційно-можлива кількість дослідів становить $n^{\prime}$, в результаті виконання яких виявилось число “успіхів” $k^{\prime}$. Можна справедливо очікувати, що показники якості оцінки для результату $k^{\prime}$ при тому, що $n^{\prime}<n$, будуть гіршими (що можна побачити при аналізі табл. 1-2). Але може трапитись випадок, коли статистична частота “успіху” $W$ може перевищувати початкову ймовірнісну характеристику $p$ (для випадку $p \leq p^{*} \leq 1$, і навпаки, бути меншою для випадку $0 \leq p^{*} \leq p$ ), тобто $\frac{k^{\prime}}{n^{\prime}}>\frac{k}{n}$, а показники якості оцінки фактично будуть визначатися виразом

$$
\frac{x_{\gamma^{\prime}}}{\varepsilon^{\prime}}=\sqrt{\frac{n^{\prime}}{p^{*} q^{*}}} ; q^{*}=1-p^{*} .
$$

Мінімально-необхідна кількість повторень випробування $n$ для різних значень початкової ймовірнісної характеристики

\begin{tabular}{|c|c|c|c|c|c|c|c|c|c|c|c|c|c|c|c|c|}
\hline \multirow{3}{*}{$p$} & \multicolumn{4}{|c|}{$\gamma \geq 0,8$} & \multicolumn{4}{|c|}{$\gamma \geq 0,9$} & \multicolumn{4}{|c|}{$\gamma \geq 0,95$} & \multicolumn{4}{|c|}{$\gamma \geq 0,99$} \\
\hline & \multicolumn{4}{|c|}{$\varepsilon$} & \multicolumn{4}{|c|}{$\varepsilon$} & \multicolumn{4}{|c|}{$\varepsilon$} & \multicolumn{4}{|c|}{$\varepsilon$} \\
\hline & 0,05 & 0,1 & 0,15 & 0,2 & 0,05 & 0,1 & 0,15 & 0,2 & 0,05 & 0,1 & 0,15 & 0,2 & 0,05 & 0,1 & 0,15 & 0,2 \\
\hline 0,6 & 160 & 40 & 18 & 10 & 262 & 66 & 30 & 17 & 369 & 93 & 41 & 24 & 640 & 160 & 72 & 40 \\
\hline 0,7 & 140 & 35 & 16 & 9 & 229 & 58 & 26 & 15 & 323 & 81 & 36 & 21 & 560 & 140 & 63 & 35 \\
\hline
\end{tabular}


Закінчення табл. 1

\begin{tabular}{|c|c|c|c|c|c|c|c|c|c|c|c|c|c|c|c|c|}
\hline \multirow{3}{*}{$p$} & \multicolumn{4}{|c|}{$\gamma \geq 0,8$} & \multicolumn{4}{|c|}{$\gamma \geq 0,9$} & \multicolumn{4}{|c|}{$\gamma \geq 0,95$} & \multicolumn{4}{|c|}{$\gamma \geq 0,99$} \\
\hline & \multicolumn{4}{|c|}{$\varepsilon$} & \multicolumn{4}{|c|}{$\bar{\varepsilon}$} & \multicolumn{4}{|c|}{$\varepsilon$} & \multicolumn{4}{|c|}{$\varepsilon$} \\
\hline & 0,05 & 0,1 & 0,15 & 0,2 & 0,05 & 0,1 & 0,15 & 0,2 & 0,05 & 0,1 & 0,15 & 0,2 & 0,05 & 0,1 & 0,15 & 0,2 \\
\hline 0,8 & 107 & 27 & 12 & 7 & 175 & 44 & 20 & 11 & 246 & 62 & 28 & 16 & 427 & 107 & 48 & 27 \\
\hline 0,9 & 60 & 15 & 7 & 4 & 99 & 25 & 11 & 7 & 139 & 35 & 16 & 9 & 240 & 60 & 27 & 15 \\
\hline 0,95 & 32 & 8 & 4 & 2 & 52 & 13 & 6 & 4 & 73 & 19 & 9 & 5 & 127 & 32 & 15 & 8 \\
\hline 0,99 & 7 & 2 & 1 & 1 & 11 & 3 & 2 & 1 & 16 & 4 & 2 & 1 & 27 & 7 & 3 & 2 \\
\hline
\end{tabular}

Джерело: розроблено авторами за даними [25, С. 148].

Таблиця 2

Очікуване число “успіхів” $k$

\begin{tabular}{|c|c|c|c|c|c|c|c|c|c|c|c|c|c|c|c|c|}
\hline \multirow{3}{*}{$p$} & \multicolumn{4}{|c|}{$\gamma \geq 0,8$} & \multicolumn{4}{|c|}{$\gamma \geq 0,9$} & \multicolumn{4}{|c|}{$\gamma \geq 0,95$} & \multicolumn{4}{|c|}{$\gamma \geq 0,99$} \\
\hline & \multicolumn{4}{|c|}{$\bar{\varepsilon}$} & \multicolumn{4}{|c|}{$\bar{\varepsilon}$} & \multicolumn{4}{|c|}{$\varepsilon$} & \multicolumn{4}{|c|}{$\bar{\varepsilon}$} \\
\hline & 0,05 & 0,1 & 0,15 & 0,2 & 0,05 & 0,1 & 0,15 & 0,2 & 0,05 & 0,1 & 0,15 & 0,2 & 0,05 & 0,1 & 0,15 & 0,2 \\
\hline 0,6 & 96 & 24 & 11 & 6 & 157 & 40 & 18 & 10 & 221 & 56 & 25 & 14 & 384 & 96 & 43 & 24 \\
\hline 0,7 & 98 & 25 & 11 & 6 & 160 & 41 & 18 & 11 & 226 & 57 & 25 & 15 & 392 & 98 & 44 & 25 \\
\hline 0,8 & 86 & 22 & 10 & 6 & 140 & 35 & 16 & 9 & 197 & 50 & 23 & 13 & 342 & 86 & 39 & 22 \\
\hline 0,9 & 54 & 14 & 7 & 4 & 89 & 23 & 10 & 7 & 125 & 32 & 15 & 8 & 216 & 54 & 25 & 14 \\
\hline 0,95 & 31 & 8 & 4 & 2 & 50 & 13 & 6 & 4 & 70 & 18 & 9 & 5 & 121 & 31 & 15 & 8 \\
\hline 0,99 & 7 & 2 & 1 & 1 & 11 & 3 & 2 & 1 & 16 & 4 & 2 & 1 & 27 & 7 & 3 & 2 \\
\hline
\end{tabular}

Джерело: розроблено авторами за даними [25, С. 150].

У цій ситуації заміна початкової імовірнісної характеристики $p$ підтвердженою ймовірністю $p$ *, в окремих випадках, може покращити співвідношення надійності і точності оцінки, так як бажаним результатом безумовно $є$ максимізація відношення $\frac{x_{\gamma^{\prime}}}{\varepsilon^{\prime}}$.

Розглянемо приклад. Нехай початкова характеристика задана як “не гірше ніж” $p \geq 0,8$; параметри якості оцінки $\gamma \geq 0,95 ; \varepsilon \leq 0,1$. Тоді 3 табл. $1-2$ : $n=62$ і $k=50$. Нехай потенційно можлива кількість повторень складає третину від розрахованого, тобто $n^{\prime}=21$, при виконанні яких одержано "успіхів" $k^{\prime}=20$. При цьому статистична частота становитиме $W=0,95$. Результати співвідношення між надійністю і точністю для випадків балансу $\varepsilon(\gamma)$ i $\varepsilon^{\prime}\left(\gamma^{\prime}\right)$ наведені на графіку рис. 4.

3 графіку рис. 4 видно, що співвідношення надійності і точності є “кращими" при кількості випробувань $3 \quad n^{\prime}=21$ ніж $n=62$ (для надійності $\gamma^{\prime} \geq 0,95$ одержане значення точності $\varepsilon \leq 0,091$ при $n^{\prime}=21$ ), проте зауважимо, що це виявилось лише після проведення всієї кількості повторень 3 одержанням непоганих результатів і статистичною частотою $W$ більшою за початкову імовірнісну характеристику $p$ для випадку реалізації стохастичної величини “не гірше ніж”.
Зауважимо, що таке "покращення" параметрів оцінки результатів випробування є скоріше виключенням, ніж правилом.

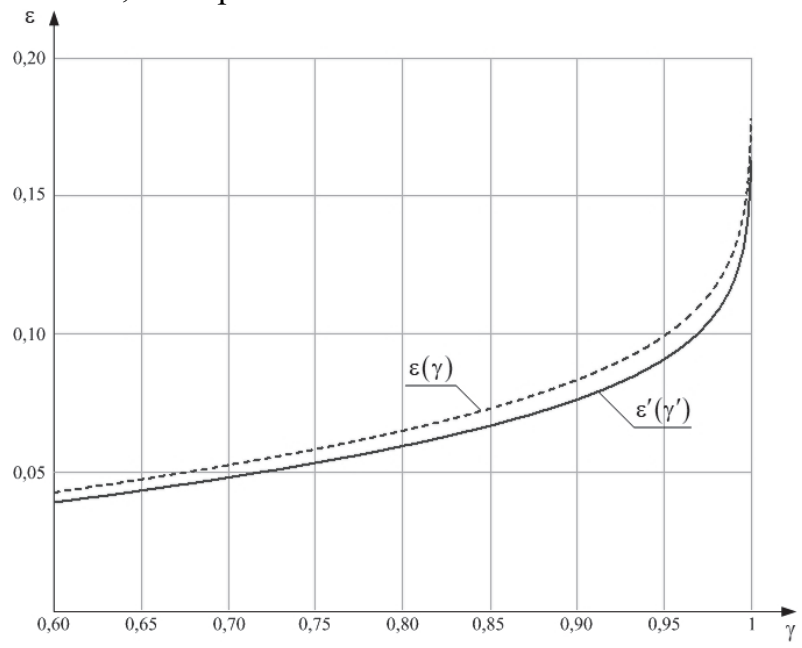

Рис. 4. Співвідношення між показниками якості оцінки при скороченні кількості повторень дослідів для наведеного прикладу Джерело: розроблено авторами.

Як показує практика, при скороченні повторень випробування їх загальна кількість налічує одиниці, в результаті чого при зростанні статистичної частоти чисельник підкореневого відношення правої частини виразу (5) убуває стрімкіше, ніж знаменник. Це, в кінцевому рахунку, не збільшує відношення $\frac{x_{\gamma^{\prime}}}{\varepsilon^{\prime}}$, i не покращує показники якості оцінки. 
Блок схема алгоритму розрахунку показників якості оцінки результатів дослідів при скороченій кількості повторень наведена на рис. 5.

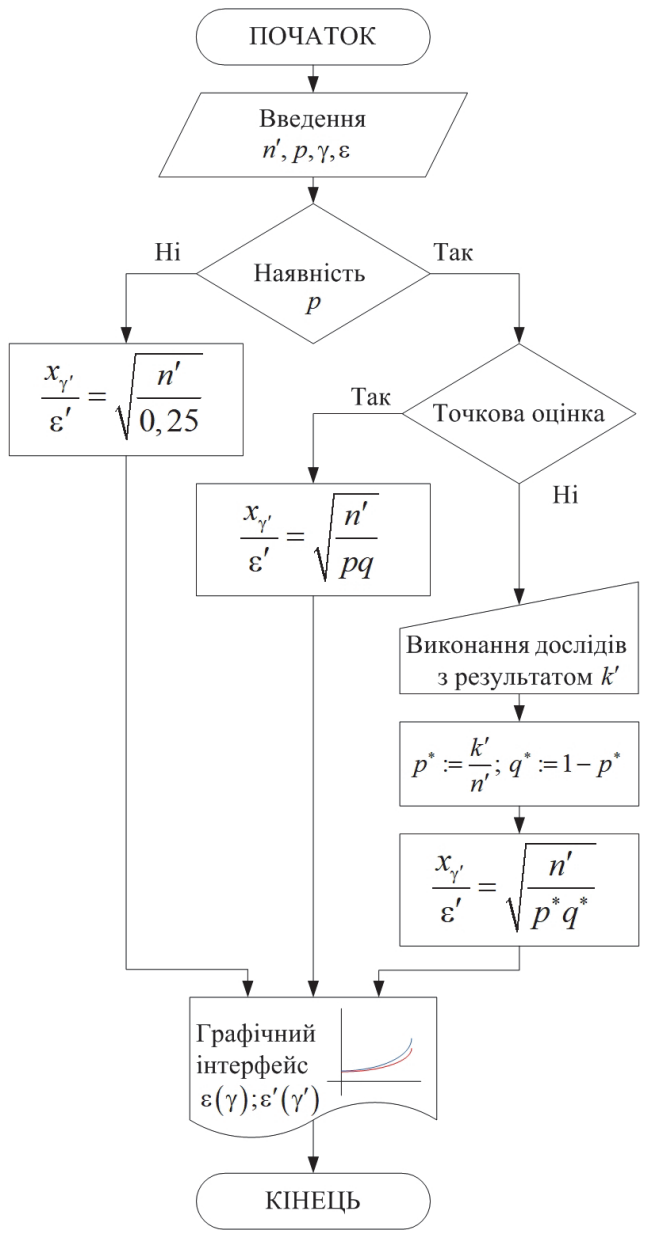

Рис. 5. Алгоритм розрахунку показників якості оцінки результатів випробування стохастичної величини при навмисному скороченні кількості повторень дослідів Джерело: розроблено авторами.

Ручному введенню (на даному етапі алгоритмування) підлягають: показники скороченої кількості повторень випробування $n^{\prime}$, за наявності початкова імовірнісна характеристика $p$, показники яко- сті оцінки $\gamma$ і $\varepsilon$. Перше вирішальне правило алгоритму відокремлює стохастичні величини, для яких не задано початкової ймовірнісної характеристики, i для яких здійснюється розрахунок на найгірший випадок повної невизначеності щодо реалізації стохастичної характеристики (показника) випробуваного зразка. Друге вирішальне правило відокремлює стохастичні величини, для яких задана початкова ймовірнісна характеристика у точковому або інтервальному вигляді. Для кожного випадку здійснюється розрахунок втрати показників якості оцінки результатів випробування. У випадку інтервальної оцінки вводяться апостеріорні дані щодо кількості “успішних" дослідів, та на основі цього розраховуються показники якості оцінки.

\section{Висновки}

В реальних умовах випробувань зразків ОВТ нерідко трапляються випадки навмисного скорочення кількості повторень дослідів. Такі випадки, як правило, пов'язані з об'єктивними причинами, проте вимагають аналізу наслідків таких скорочень, що при дослідженні стохастичних величин виражаються у параметрах якості оцінки результатів досліджень.

Нами розглянуто питання одержання параметрів якості оцінок для трьох можливих випадків проведення випробувань. Теоретично показано, що при одержанні інтервальних оцінок і позитивних результатах випробування можливі випадки збереження надійності і точності одержуваних оцінок.

Запропонований алгоритм розрахунку параметрів якості оцінок стохастичних параметрів і характеристик випробуваного зразка доцільно використати у вигляді інтегрованого модуля у складі автоматизованої інформаційної системи супроводження випробувань. Це дозволить автоматизувати процедури формування кількісних параметрів дослідів при підготовці методик випробування та оформленні звітних матеріалів.

\section{Список літератури}

1. Формування параметрів вхідного потоку вимог на випробування озброєння і військової техніки / І.В. Корнієнко, С.П. Корнієнко, В.А. Дмитрієв, А.Г. Павленко, Д.О. Камак // Озброєння та військова техніка. - 2020. - № 3(27). C. 95-102. https://doi.org/1034169/2414-0651.2020.3(27).95-102.

2. Investigation of the Model of Testing for Weapons and Military Equipment / I. Korniienko, S. Korniienko, V. Dmytriiev, A. Pavlenko, D. Kamak // Mathematical Modeling and Simulation of Systems (MODS'2020). MODS 2020. - Springer, Cham. P. 309-316. https://doi.org/10.1007/978-3-030-58124-4_30.

3. ДСТУ 3021-95. Випробування і контроль якості продукції. Терміни та визначення. - К., 1995. - 71 с.

4. Постанова Кабінету Міністрів України № 120 від 20.02.2013 року “Про затвердження Порядку розроблення, освоєння та випуску нових видів продукції оборонного призначення, а також припинення випуску існуючих видів такої продукціï” [Електронний ресурс]. - Режим доступу: https://zakon.rada.gov.ua/laws/show/120-2013-\%D0\%BF\#Text.

5. Постанова Кабінету Міністрів України № 345 від 25.02.2015 року “Про затвердження Порядку постачання озброєння, військової та спеціальної техніки та боєприпасів під час особливого періоду, введення надзвичайного стану, проведення заходів із забезпечення національної безпеки і оборони, відсічі і стримування збройної агресії та у період проведення антитерористичної операції” [Електронний ресурс]. - Режим доступу: https://zakon.rada.gov.ua/laws/show/345-2015-\%D0\%BF\#Text. 
6. ГОСТ В 15.210-78. СРПП ВТ. Система разработки и постановки на производство военной техники. Испытания опытных образцов изделий. - М., 1978. - 35 с.

7. ГОСТ В 15.211-78. СРПП ВТ. Порядок разработки программ и методик испытаний опытных образцов изделий. Основные положения. - М., 1978. - 23 с.

8. ГОСТ В 15.307-77. СРПП ВТ. Испытания и приемка серийных изделий. Основные положения. - М., 1977. - 36 с.

9. Хартман К. Планирование эксперимента в исследовании технологических процессов / К. Хартман, Э. Лецкий, В. Шеффер. - М.: Мир, 1977. - 541 с.

10. Джонсон Н. Статистика и планирование эксперимента в технике и науке: Методы планирования эксперимента / Н. Джонсон, Ф. Лион. - М.: Мир, 1981. - 520 с.

11. Дмитриев А.К. Элементы теории испытаний и контроля технических систем / А.К. Дмитриев, В.М. Марков, В.И. Городецкий. - Ј.: Энергия, 1978. - 192 с.

12. Демидов Б.А. Теория и методы военно-научных исследований вооружения и военной техники / Б.А. ДемидовХ: ВИРТА ПВО, 1990. -558 с.

13. Основы военно-технических исследований. Теория и приложения: монография: в 10 т. Т.9. Прикладные аспекты испытаний и теоретико-экспериментальных исследований вооружения и военной техники / И.Б. Чепков, С.В. Лапицкий и др.; под ред. С.В. Лапицкого. - К.: Издательский дом Дмитрия Бураго, 2015. - 504 с.

14. Гнєденко Б.В. Курс теорії ймовірностей / Б.В. Гнєденко. - К.: Рад. шк., 1949. - 360 с.

15. Гмурман В. Теория вероятностей и математическая статистика /В. Гмурман - М.: Высшая школа, 1977. - 479 с.

16. Вентцель Е.С. Теория вероятностей и ее инженерные приложения / Е.С. Вентцель, Л.А. Овчаров. - М.: Наука, 1988. $-480 \mathrm{c}$.

17. Ланецький Б.М. Проблемні питання організації та планування випробувань складних технічних систем / Б.М. Ланецький, В.В. Лук'янчук // Системи обробки інформації. - 2009. - № 4(78). - С. 93-96.

18. Щапов П.Ф. Методи підвищення вірогідності контролю та діагностики стохастичних параметрів об'єктів різної фізичної природи: автореф. дис. ... д-ра техн. наук: спец 05.11.13: Прилади і методи контролю та визначення складу речовин. - Х., 2009. - 39 с.

19. Кошевая Л.А. Обеспечение единства испытаний. Концептуальные основы: монография / Л. А. Кошевая. - К.: HAУ, 2009. - $176 \mathrm{c}$.

20. Планування експерименту при розв'язанні оберненої задачі побудови толерантних (референсних) інтервалів / С.В. Гадецька, В.Ю.Дубницький, Ю.І. Кушнерук, О.І. Ходирєв // Системи обробки інформації. - 2020. - № 2(161). C. 37-46. https://doi.org/10.30748/soi.2020.161.05.

21. Кобзєв В.В. Планування двоступеневих вибіркових випробувань виробів одноразового застосування на надійність $з$ урахуванням апріорної інформації / В.В. Кобзєв, В.А. Васильєв, Д.В. Фоменко // Системи обробки інформації. 2013. - № 6(113). - C. 86-89.

22. Лантух-Лященко А.І. Стохастична експертна оцінка технічного стану споруди в автоматизованій системі управління мостами / А.І. Лантух-Лященко // Мости та тунелі: теорія, дослідження, практика. - 2019. - № 15. - С. 34-40. https://doi.org/10.15802/bttrp2019/172377.

23. Шитікова О.С. Інформаційна технологія підтримки процесу випробувань газотурбінних установок наземного використання з урахуванням невизначеності: дис. ... канд. техн. наук: 05.13.06. - Запоріжжя, 2017. - 195 с.

24. Автоматизація підсистеми планування випробувань / І.В. Корнієнко, Д.О. Камак, О.В. Руденко, С.В. Москалець // Збірник матеріалів тез доповідей X Міжнародної науково-практичної конференції "Комплексне забезпечення якості технологічних процесів та систем (КЗЯТПС - 2020)”. - Чернігів, 29-30 квітня 2020 р. - Т. 2. - С. 206.

25. Формування кількісних характеристик випробувань для одержання точкових оцінок заданої якості / С. Корнієнко, І. Корнієнко, В. Дмитрієв, А. Павленко, Д. Камак // Технічні науки та технології. - 2020. - № 1(19). - С. 140-155. https://doi.org/10.25140/2411-5363-2020-1(19)-140-155.

26. Планування кількості випробувань при інтервальних оцінках зразків ОВТ / С.П. Корнієнко, І.В. Корнієнко, Д.О. Камак, С.М. Казначей, О.В. Жирна // Збірник наукових праць Державного науково-дослідного інституту випробувань і сертифікації озброєння та військової техніки. - 2020. - № 4. - С. 46-54. https://doi.org/10.37701/dndivsovt.4.2020.06.

27. ДСТУ 3004-95. Надійність техніки. Методи оцінки показників надійності за експериментальними даними. - К., 1994. -32 c.

\section{References}

1. Korniienko, I., Korniienko, S., Dmytriiev, V., Pavlenko, A. and Kamak, D. (2020), "Formuvannia parametriv vkhidnoho potoku vymoh na vyprobuvannia ozbroiennia i viiskovoi tekhniky" [Parameters formation of the input flow of requirements for testing weapons and military equipment], Weapons and military equipment, Scientific and technical journal, No. 3(27), pp. 95-102. https://doi.org/1034169/2414-0651.2020.3(27).95-102.

2. Korniienko, I., Korniienko, S., Dmytriiev, V., Pavlenko, A. and Kamak, D. (2020), Investigation of the Model of Testing for Weapons and Military Equipment, Mathematical Modeling and Simulation of Systems (MODS'2020). MODS 2020, Springer, pp. 309-316. https://doi.org/10.1007/978-3-030-58124-4_30.

3. State Standard of Ukraine (1995), "3021-95 Vyprobuvannia i kontrol yakosti produktsii. Terminy ta vyznachennia" [3021-95 Product testing and quality control. Terms and definitions], Kyiv, 71 p.

4. The Resolution of the Cabinet of Ministers of Ukraine (2013), "Pro zatverdzhennia Poriadku rozroblennia, osvoiennia ta vypusku novykh vydiv produktsii oboronnoho pryznachennia, a takozh prypynennia vypusku isnuiuchykh vydiv takoi produktsii 
No. 120 vid 20.02.2013 r." [About the statement of the Order of development, development and release of new types of products of defense appointment, and also the termination of release of existing types of such products No. 120 dated 20.02.2013], available at: https://zakon.rada.gov.ua/laws/show/120-2013-\%D0\%BF\#Text (accessed 8 September 2020).

5. The Resolution of the Cabinet of Ministers of Ukraine (2015), "Pro zatverdzhennia Poriadku postachannia ozbroiennia, viiskovoi ta spetsialnoi tekhniky ta boieprypasiv pid chas osoblyvoho periodu, vvedennia nadzvychainoho stanu, provedennia zakhodiv iz zabezpechennia natsionalnoi bezpeky i oborony, vidsichi i strymuvannia zbroinoi ahresii ta u period provedennia antyterorystychnoi operatsii No. 345 vid 25.02.2015 r." [About the statement of the Order of delivery of the armament, military and special equipment and ammunition during the special period, introduction of a state of emergency, carrying out of measures for ensuring national security and defense, repulse and deterrence of armed aggression and during anti-terrorist operation No. 345 dated 25.02.2015], available at: https://zakon.rada.gov.ua/laws/show/345-2015-\%D0\%BF\#Text (accessed 8 September 2020).

6. State Standard of USSR (1978), "V 15.211-78. SRPP VT Sistema razrabotki i postanovki na proizvodstvo voennoy tehniki. Ispyitaniya opyitnyih obraztsov izdeliy" [V 15.211-78. SRPP VT The system for the development and production of military equipment. Testing of prototypes of products ], Moscow, $35 \mathrm{p}$.

7. State Standard of USSR (1978), "V 15.211-78. SRPP VT. Poryadok razrabotki programm i metodik ispyitaniy opyitnyih obraztsov izdeliy. Osnovnyie polozheniya" [V 15.211-78. SRPP VT. The order of development of programs and methods of tests of prototypes of products. Basic provisions], Moscow, $23 \mathrm{p}$.

8. State Standard of USSR (1977), "V 15.307-77. SRPP VT. Ispyitaniya i priemka seriynyih izdeliy. Osnovnyie polozheniya" [V 15.307-77. SRPP VT. Testing and acceptance of serial products. Basic provisions], Moscow, $36 \mathrm{p}$.

9. Khartman, K., Letckii, E. and Shefer, V. (1977), "Planirovanie eksperimenta v issledovanii tekhnologicheskikh protcessov" [Planning an experiment in the study of technological processes], Mir, Moscow, $541 \mathrm{p}$.

10. Dzhonson, N. and Lion, F. (1981), "Statistika i planirovanie eksperimenta v tehnike i nauke: Metodyi planirovaniya eksperimenta" [Statistics and experiment planning in engineering and science: Experiment planning methods], Mir, Moscow, $520 \mathrm{p}$.

11. Dmitriev, A.K., Markov, V.M. and Gorodetskiy, V.I. (1978), "Elementyi teorii ispyitaniy kontrolya tehnicheskih sistem" [Elements of the theory of testing the control of technical systems], Energiya, Leningrad, $192 \mathrm{p}$.

12. Demidov, B.A. (1990), "Teoriya i metodyi voenno-nauchnyih issledovaniy vooruzheniya $i$ voennoy tehniki" [Theory and methods of military scientific research of weapons and military equipment], VIRTA PVO, Kharkov, $558 \mathrm{p}$.

13. Chepkov, I.B. and Lapytskyi, S.V. (2015). "Osnovyi voenno-tehnicheskih issledovaniy. Teoriya i prilozheniya: monografiya: $v 10$ t. T. 9. Prikladnyie aspektyi ispyitaniy i teoretikoeksperimentalnyih issledovaniy vooruzheniya $i$ voennoy tehniki" [Fundamentals of military-technical research. Theory and applications: monograph: in 10 volumes. Vol. 9. Applied Aspects of Testing and Theoretical Experimental Research of Weapons and Military Equipment], Izdatelskiy dom Dmitriya Burago, Kyiv, 504 p.

14. Hniedenko, B.V. (1949). "Kurs teorii ymovirnostei” [Course in probability theory], Rad. Shk., Kyiv, 360 p.

15. Gmurman, V.E. (1977). "Teoriia veroiatnostei i matematicheskaia statistika" [Theory of probability and mathematical statistics], Vysshaia shkola, Moscow, $479 \mathrm{p}$.

16. Venttcel, E.S. and Ovcharov, L.A. (1988), "Teoriia veroiatnostei i ee inzhenernye prilozheniia" [Probability Theory and Its Engineering Applications], Nauka, Moscow, $480 \mathrm{p}$.

17. Lanetskyi, B.M. (2009), "Problemni pytannia orhanizatsii ta planuvannia vyprobuvan skladnykh tekhnichnykh system" [Problem-solving questions of the organization and the planning the test the complex technical systems], Information Processing Systems, No. 4(78), pp. 93-96.

18. Shchapov, P.F. (2009). "Metody pidvyshchennia virohidnosti kontroliu ta diahnostyky stokhastychnykh parametriv obiektiv riznoi fizychnoi pryrody: dissertation abstract" [Methods to increase the probability of control and diagnosis of stochastic parameters of objects of different physical nature: dissertation abstract], Kharkiv, $39 \mathrm{p}$.

19. Koshevaia, L.A. (2009), "Obespechenie edinstva ispytanii. Kontceptualnye osnovy: monografiia" [Ensuring the unity of testing. Conceptual bases: monograph], NAU, Kyiv, 176 p.

20. Hadetska, S.V., Dubnytskyi, V.Iu., Kushneruk, Yu.I. and Khodyriev, O.I. (2020), "Planuvannia eksperymentu pry rozviazanni obernenoi zadachi pobudovy tolerantnykh (referensnykh) intervaliv" [Experiment planning when solving the inverse problem of constructing tolerant (reference) intervals], Information Processing Systems, No. 2(161), pp. 37-46. https://doi.org/10.30748/soi.2020.161.05.

21. Kobziev, V.V. (2013), "Planuvannia dvostupenevykh vybirkovykh vyprobuvan vyrobiv odnorazovoho zastosuvannia na nadiinist $\mathrm{z}$ urakhuvanniam apriornoi informatsii" [Two-stage selective reliability tests planning of single application products with a priori information including], Information Processing Systems, No. 6(113), pp. 86-89.

22. Lantukh-Liashchenko, A.I. (2019). "Stokhastychna ekspertna otsinka tekhnichnoho stanu sporudy v avtomatyzovanii systemi upravlinnia mostamy" [Stochastic expert assessment of the technical condition of the structure in the automated bridges control system], Bridges and tunnels: theory, research, practice, No. 15, pp. 34-40. https://doi.org/10.15802/bttrp2019/172377.

23. Shytikova, O.S. (2017), "Informatsiina tekhnolohiia pidtrymky protsesu vyprobuvan hazoturbinnykh ustanovok nazemnoho vykorystannia z urakhuvanniam nevyznachenosti: dissertation" [Information technology to support the process of viptesting of gas-turbine installations of a ground-based victorious plant for reasons of non-importance: dissertation], Zaporizhzhya, $195 \mathrm{p}$.

24. Korniienko, I.V., Kamak, D.O., Rudenko, O.V. and Moskalets, S.V. (2020), “Avtomatyzatsiia pidsystemy planuvannia vyprobuvan" [Automation of the test planning subsystem], Comprehensive quality assurance of technological processes and systems, Vol. 2, Chernihiv, pp. 206. 
25. Korniienko, S., Korniienko, I., Dmytriiev, V., Pavlenko, A. and Kamak, D. (2020), "Formuvannia kilkisnykh kharakterystyk vyprobuvan dlia oderzhannia tochkovykh otsinok zadanoi yakosti" [Formation of quantitative characteristics of tests to obtain point estimates of a given quality], Technical Sciences and Technologies: scientific journal, No. 1(19), pp. 140-155. https://doi.org/10.25140/2411-5363-2020-1(19)-140-155.

26. Korniienko, S.P., Korniienko, I.V., Kamak, D.O., Kaznachei, S.M. and Zhyrna, O.V. (2020), "Planuvannia kilkosti vyprobuvan pry intervalnykh otsinkakh zrazkiv OVT" [Planning the number of tests in interval assessments of samples of weapons and military equipment], Scientific works of State Scientific Research Institute of Armament and Military Equipment Testing and Certification, No. 2(4), pp. 46-54. https://doi.org/10.37701/dndivsovt.4.2020.06.

27. State Standard of Ukraine (1995), "3004-95 Nadiinist tekhniky. Metody otsinky pokaznykiv nadiinosti za eksperymentalnymy danymy" [3004-95 Reliability of technology. Methods for estimating the reliability of the experimental data], Kyiv, $32 \mathrm{p}$.

Надійшла до редколегії 09.09.2020

Схвалена до друку 13.10.2020

\section{Відомості про авторів:}

\section{Корніснко Ігор Валентинович}

кандидат технічних наук доцент завідувач кафедри

Національного університету “Чернігівська політехніка”, Чернігів, Україна

https://orcid.org/0000-0001-9105-0780

\section{Корніснко Світлана Петрівна} кандидат технічних нау, доцент доцент кафедри Національного університету

"Чернігівська політехніка",

Чернігів, Україна

https://orcid.org/0000-0002-9162-1229

\section{Дмитрісв Володимир Анатолійович}

кандидат технічних наук

старший науковий співробітник

заступник начальника інституту з наукової роботи

Державного науково-дослідного інституту випробувань і сертифікації озброєння та військової техніки,

Чернігів, Україна

https://orcid.org/0000-0002-0792-6397

Павленко Анатолій Григорович
кандидат технічних наук
начальник науково-організаційного відділу
Державного науково-дослідного інституту випробувань
i сертифікації озброєння та військової техніки,
Чернігів, Україна
https://orcid.org/0000-0001-6341-8381

\section{Камак Дмитро Олександрович}

начальник науково-дослідного відділу

Державного науково-дослідного інституту випробувань і сертифікації озброєння та військової техніки,

Чернігів, Україна

https://orcid.org/0000-0003-0348-5456

\section{Information about the authors:}

Ihor Korniienko

Candidate of Technical Sciences Associate Professor

Head of Department

of Chernihiv Polytechnik National University,

Chernihiv, Ukraine

https://orcid.org/0000-0001-9105-0780

\section{Svitlana Korniienko}

Candidate of Technical Science Associate Professor

Senior Lecturer of the Department

of Chernihiv Polytechnik National University,

Chernihiv, Ukraine

https://orcid.org/0000-0002-9162-1229

Volodymyr Dmytriiev

Candidate of Technical Sciences

Senior Research

Deputy Chief of Institute of Research Work

of State Scientific Research Institute of Armament and Military Equipment Testing and Certification, Chernihiv, Ukraine

https://orcid.org/0000-0002-0792-6397

\author{
Anatolii Pavlenko \\ Candidate of Technical Sciences \\ Chief of the Scientific Organizational Department \\ of State Scientific Research Institute of Armament \\ and Military Equipment Testing and Certification, \\ Chernihiv, Ukraine \\ https://orcid.org/0000-0001-6341-8381

\section{Dmytro Kamak} \\ Chief of the Scientific-Research Department \\ of State Scientific Research Institute of Armament \\ and Military Equipment Testing and Certification, \\ Chernihiv, Ukraine \\ https://orcid.org/0000-0003-0348-5456
}

\title{
ОПРЕДЕЛЕНИЕ ПАРАМЕТРОВ КАЧЕСТВА ОЦЕНОК СТОХАСТИЧЕСКИХ ХАРАКТЕРИСТИК ИСПЫТАНИЙ ОБРАЗЦОВ ВООРУЖЕНИЯ И ВОЕННОЙ ТЕХНИКИ
}

\author{
И.В. Корниенко, С.П. Корниенко, В.А. Дмитриев, А.Г. Павленко, Д.О. Камак
}

Обеспечение точности и надежности оченок стохастических характеристик и параметров исследуемых образиов является одной из самых сложных задач при испытании вооружения и военной техники. Проблема возникает на этапе формирования статистического материала о результатах испытаний, достаточными объемами которого обеспечивается качество оценки. Однако, в силу объективных причин, минимально необходимое количество повторений в опыте при испытании изделий военного назначения может быть ниже нужного, что связано с материальными, экономическими, физическими, экологическими ограничениями и т.д. При этом расчет показателей качества оценок результатов исследований стохастических величин остается обязательным атрибутом испытаний. 
В статье рассмотрены теоретические вопросы формирования показателей качества оценок стохастических величин с использованием математического аппарата теории вероятностей. Обоснованы варианты расчетов показателей качества оченки для случаев отсутствия или наличия начальных вероятностных характеристик, точечных или интервальных оценок стохастической величины. Для случая интервального оценивания показана теоретическая возможность сохранения значений показателей качества оценок при умышленном сокращении количества повторений в опыте при условии получения положстельных результатов исследований. Предложено использование графического интерфейса для нахождения оптимального баланса между точностью и надежностью получаемых оценок.

Для практической реализации разработан алгоритм расчета точности и надежности оченок стохастических характеристик (параметров) испытуемого образиа, который можно использовать в основе функционального модуля 8 подсистемы планирования испытаний автоматизированной системы сопровождения испытаний вооружения и военной техники. Автоматизация расчета показателей качества оиенки стохастических величин может оказаться полезной при разработке программы и методики испытания образцов вооружения и военной техники, а также при оценке достоверности и качества результатов испытаний при формировании актов и составлении отчетов по испытанию.

Ключевые слова: автоматизация, испытания, оценка, точность, надежность, вооружение и военная техника.

\section{DETERMINATION OF QUALITY PARAMETERS OF ESTIMATIONS OF STOCHASTIC CHARACTERISTICS OF THE TEST SAMPLE OF WEAPONS AND MILITARY EQUIPMENT}

\section{Korniienko, S. Korniienko, V. Dmytriiev, A. Pavlenko, D. Kamak}

Ensuring the accuracy and reliability of estimates of stochastic characteristics and parameters of the studied samples is one of the most difficult tasks in testing weapons and military equipment. The problem arises at the stage of formation of statistical material on test results, sufficient volumes of which ensure the quality of the assessment. However, due to objective reasons, the minimum required number of repetitions of experiments on military products may be lower than required, due to material, economic, physical, environmental constraints and so on. In this case, the calculation of quality indicators for evaluating the results of studies of stochastic quantities remains a mandatory attribute of the tests.

The article considers theoretical issues of formation of quality indicators of estimates of stochastic quantities using the mathematical apparatus of probability theory. Variants of calculations of estimation quality indicators for cases of absence or presence of initial probabilistic characteristics, point or interval estimations of stochastic quantity are substantiated. The theoretical possibility of preserving the values of evaluation quality indicators for the case of interval evaluation with the deliberate reduction of the number of repetitions of experiments under the condition of obtaining positive research results is shown. The use of a graphical interface to find the optimal balance between accuracy and reliability of the obtained estimates is proposed.

For practical implementation, an algorithm for calculating the accuracy and reliability of estimates of stochastic characteristics (parameters) of the test sample, which can be used as a functional module in the test planning subsystems of the automated support system for testing weapons and military equipment. Automation of the calculation of quality indicators of the estimate of stochastic quantities can be useful in developing a program and methods for testing samples of weapons and military equipment, as well as in estimating the reliability and quality of test results in the formation of acts and reports of tests.

Keywords: automation, testing, estimation, accuracy, reliability, armament and military equipment. 